\title{
総合論 文
}

\section{低級オレフィンからガソリンの高選択的合成}

\author{
乾智 行* \\ Highly Selective Synthesis of Gasoline from Light Olefins.
}

Tomoyuki INUI*

\begin{abstract}
Selective synthesis of high octane value gasoline from light olefins was investigated by developing novel shape-selective metallosilicates. The metallosilicates were synthesized by replacing the Al ingredient of ZSM-5 zeolite with various metal at the stage of gel formation in the rapid crystallization method. Among various metallosilicates, iron-group metal silicates were found to exhibit the highest selectivity to light olefins from methanol. Therefore, preparation method of the $\mathrm{Fe}$-silicate was studied more extensively. It was proved that the $\mathrm{Fe}$ ingredient is concentrated in the core part of the crystal particles, especially in $\mathrm{Fe}$-silicates having high $\mathrm{Si} / \mathrm{Fe}$ atomic ratios, and the particles are covered by $\mathrm{Fe}$-poor silica layer. Light olefins were exclusively converted to gasoline on these $\mathrm{Fe}$-silicates; e. g. $95.6 \%$ propylene fed was converted to a high octane value (95) gasoline with a very high space-time yield $(8.09 \mathrm{~kg} / \mathrm{l} \cdot \mathrm{h})$ at $295^{\circ} \mathrm{C}$ and a space velocity of $4,500 \mathrm{~h}^{-1}$. The catalytic activity of the $\mathrm{Fe}$-silicate for propylene conversion and the selectivity to gasoline was consistently maintained at least $100 \mathrm{~h}$ on stream under the corresponding condition of SV $1,000 \mathrm{~h}^{-1}$.
\end{abstract}

\section{1. はじめに}

石油危機以来, 鉄鋼業, セメント製造業, 火力発電業 などで, 重質油系燃料に替えて, 石炭など石油代替燃料 への切り替えが進められた。このため, 原油の半分強を 占める重質油の新しい有効な利用途の開発が急がれるこ とになった。重質油は, 高温で熱分解して, 低級パラフ ィン類, 低級オレフィン類, ガソリン, 中間留出油, ピ ッチ,コークスなどに変換されるが, 付加価值の大きい ガソリンの収率は高くない。そこで, 生成する低級オレ フィン類を収率よくガソリンに変換できれば，重質油の 有効利用率は著しく高くなる。

また，わが国では原油の軽質分のナフサを熱分解して 石油化学の主要な基本原料であるエチレンを得ているが, このとき副生するプロピレンやブテンは需要を上まわり, その有効利用が待たれている。更に, 米国やカナダでは, 天然ガス中のエタンを脱水素してェチレンを生産してい

\footnotetext{
* 京都大学工学部石油化学教室

* Department of Hydrocarbon Chemistry, Faculty of Engineering, Kyoto University
}

るので, 余㮃のプロパン, ブタンの有効利用の道として， 脱水素後ガソリンに変換する目標が重視されつつある。 このように, プロピレンやブテン, あるいは $\mathrm{C}_{2} \sim \mathrm{C}_{4}$ オ レフィンの混合物をガソリンに変換する課題が意義を増 している。

一方, 石炭を一次資源として, 液体燃料や石油化学工 業原料を合成する課題は, 新エネルギー資源の合成と次 世代の有機化学工業体系を形造るものとして, 石油危機 以来研究が盛んになっている。なかでも，石炭をガス化 して得られる合成ガス，あるいは合成ガスから既存の技 術により大量生産が可能なメタノールから，オレフィン を合成して石油化学上業り原料に供する螌媒技術を確立 することが特に重視される って合成されるオレンフィンをさらにガソリンに変換する 触媒技術を開発して結べば，石炭のいわゆる間接液化技 術が高い水準で完成に向うことが期待される。

本稿では，このような意義をもつオレフィンからガソ リンを合成する課題を中心に, 筆者らが数年来進めてき た研究の経緯と成果を総括する。

2. 従来法重合ガソリン

低級オレフィンの低重合（オリゴメリゼーション）に 
よるいわゆる重合ガソリンを生成する反応については, かって, 固体リン酸, 担持酸化ニッケルなどの固体触媒, あるいは, リン酸, 硫酸 $(95 \%$ 硫酸に硫酸第一水銀を $2 \%$ と硫酸銅を $5 \%$ 添加溶解したもの）などの液状触媒 によって行われた ${ }^{4,5)}$ 。例えば, 固体リン酸触媒と呼ば れるものは，5価のリン酸とケイソー土を混合し，アル ミナ, マグネシア, 酸化亜鉛, ケイ酸アルミニウムなど の助触媒を加えて焼成を経て製造され，エチレンの重合 の場合, $296{ }^{\circ} \mathrm{C}, 36.5 \mathrm{~atm}$, 接触時間 1,400 秒といった条 件で反応させられ，転化率 $86.3 \mathrm{wt} \%$ にて，生成液状物 の選択率は $73.7 \mathrm{wt} \%$ で，パラフィン，オレフィンのほ か, シクロパラフィンや芳香族が含まれる。担持 $\mathrm{Ni}$ 触 媒では, 通常 $280 \sim 300{ }^{\circ} \mathrm{C}$ でェチレンから無色の液状物 が得られ, それ以上の温度では脱水素反応や水素化分解 反応が盛んになり,メタン，水素の生成が多くなるほか， 触媒上へ炭素が析出するようになる。低級オレフィンほ ど重合しやすく, エチレン, プロピレン, 1-ブテンの重 合速度の比は $100: 10: 1$ 程度である。

これらの例のように, 全般に反応速度は遅く, 苛酷な 反応条件を要し, 反応の選択性が不良で, 併発する分解 反応に伴う炭素析出により触媒寿命が短い。また, 生成 ガソリンも $\alpha$-オレフィン分が多くオクタン価が低い, リ ン酸, 硫酸など装置腐触の問題も伴うなど, 触媒技術と しては極めて完成度の低い状態にあったと言えよう。

\section{5. 形状選択性ゼオライト触媒 ZSM-5 と ZSM-34 の意義と限界}

第二次大戦終了までにドイッと日本では，Co 系ある いは Fe 系混合酸化物を触媒として合成ガスから石油の 合成を行ったが，生成物のうちガソリン留分 $\left(\mathrm{C}_{5} \sim \mathrm{C}_{12}\right)$ の選択率は高々 $40 \%$ に過ぎず，しかも $n$-パラフィンを 多く含むためオクタン価は 53 程度に低く，これを使用 できるガソリンとするには異性化などの接触改質が必要 とされた ${ }^{6)}$ 。これらの触媒では, 生成炭化水素の分布が Schulz-Flory 重合確率則に従うことによる。

米国 Mobil 社では 1960 年代に, 接触分解触媒用に耐 熱性と疎水性の高いゼオライト触媒の改良を続ける過程 で酸素 10 員環の新型ゼオライトZSM-5 を合成した。 結晶中の $\mathrm{Si} / \mathrm{Al}$ 原子比は, 31 を典型として同比数千程 度まで変えられ， $\mathrm{Al}$ 含量を下げることができる。酸性 量は, このような微量の範囲まで, 含有 $\mathrm{Al}$ 量に比例す ると観測されている7゙。このゼオライトの合成には，通 常 20 時間ないし 2 週間の水熱合成時間を要している。

第一次石油危機後, 同社では, メタノールの転化にこ の ZSM-5 を触媒として試み, $343^{\circ} \mathrm{C}$, 十数気圧の条件
下で, 高オクタン価 (93) ガソリンを $80 \%$ レベルの選択 率で収得することに成功し, 現在固定床プロセス (Mobil MTG プロセス) がニュージーランドに建設中である ${ }^{2,8)}$ 。

ZSM-5 触媒によるメタノール転化生成物の特徽は, $\mathrm{C}_{12}$ 以上の炭火水素を殆ど含まない, 芳香族炭化水素に 富む，メタンはごく僅かであることで，これは ZSM-5 の 3 次元的に連結された約 $6 \AA$ 程度の円筒状細孔という 特殊な細孔構造と, ゼオライト中の $\mathrm{Al}$ 成分に由来する 強い固体酸性による。コークの前駆体となる縮合芳香族 が形成するには細孔径が狭すぎることと, また, 細孔が 3 次元的に連結しているため, コークにより細孔入口全 部が閉塞する確率が小さいことから，他のゼオライトに 比べ触媒寿命が著しく長い。

しかし，このゼオライトによって，メタノールから低 級オレフィンを得ようとしても収率は低い3,8)。をたこ のゼオライトによって, オレフィンからガソリンを得よ うとしても，後に述べる通り定量的とはならない。その 理由は, メタノールは ZSM-5 上で次のような複雑な過 程を経て進むが, 触媒の酸性が強いため, 反応を途中の

$$
\begin{aligned}
& \mathrm{CH}_{3} \mathrm{OH} \stackrel{-\mathrm{H}_{2} \mathrm{O}}{\longrightarrow} \mathrm{CH}_{3} \mathrm{OCH}_{3} \stackrel{-\mathrm{H}_{2} \mathrm{O}}{\longrightarrow} \\
& \mathrm{C}_{2} \sim \mathrm{C}_{5} \text { オレフィン } \longrightarrow \begin{array}{l}
\text { オリゴマー } \\
\mathrm{C}_{6+}^{=}
\end{array} \\
& \stackrel{-\mathrm{H}_{2}}{\longrightarrow} \text { 芳香族炭化水素 } \\
& \underset{+\mathrm{H}_{2}}{\longrightarrow} \text { 脂肪族炭化水素 }
\end{aligned}
$$

段階で止めて特定の生成物だけを得ることは難しいから である ${ }^{8)}$ 。また, 芳香族炭化水素の生成に際して生じる 水素が，中間生成物である低級オレフィンと反応して， 低級パラフィン（エタン，プロパン，ブタン）などを不 可避的に生成する。そのため, Mobil MTG プロセスで は，これらのガスを加圧下に循環し，その一部をアルキ ル化してガソリン留分に加えているが，それでも $20 \%$ 近 い選択率で低級パラフィンを副生する。また，芳香族の 選択率が高いことは，ガソリンのオクタン価向には寄与 するが, 触媒上でのコーク析出が, 縮合芳香族生成を 経由して進行するので, 他のゼオライトに比べればそ の程度が少ないとはいえ, 結局, コーク析出による触媒 劣化を伴う。

一方, ZSM-34 は, 同じく Mobil 社によって特許公 開された触媒で, メタノールを, エチレンに $50 \%, \mathrm{C}_{2} \sim$ $\mathrm{C}_{4}$ オレフィンの合計 $83 \%$ に達する選択率で変換させる とするものであるが，コーク析出が著しく，使用 2 時間 で劣化が始まる ${ }^{2,8)}$ 。酸素 12 員環, 2 次元細孔構造の才 
フレタイトに, 酸素 8 員環細孔構造のエリオナイトが内 部成長した複合結晶とされる。 $\mathrm{C}_{6}$ 以上の脂肪族や芳香族 炭化水素を殆ど生成しないことから，オフレタイトの広 孔がェリオナイトにより狭められたともみることができ $3^{8)}$ 。このゼオライトの水熱合成には，25 日ないし 196 日という極めて長時間を要し，このままでは実用触媒と して成立する見込みは少ない。

\section{4. ゼオライトの迅速水熱合成法の開発}

4. 1. ヒドロゲル状結晶前駆体からの迅速水熱合成 筆者らは, メタノールから高選択率で低級オレフィン を合成することを触媒性能の評価の基準としながら， ZSM-34 の触媒性能を改善するともに，結晶化のため の時間を大幅に短縮することを試みた。

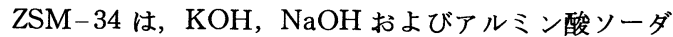
水溶液に, 有機結晶化肪として塩化コリンを原料アルカ
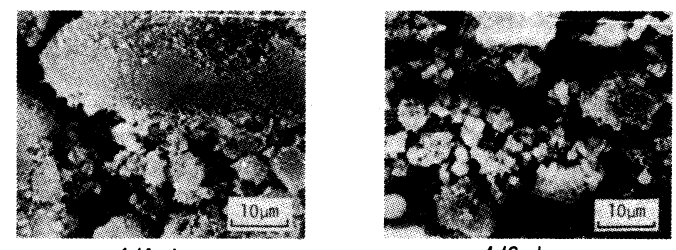

$1 / 2$ day

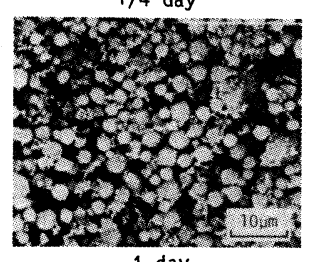

1 day
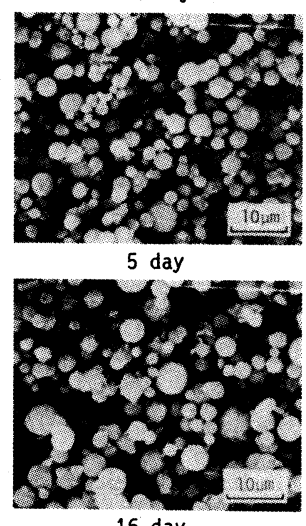

16 day

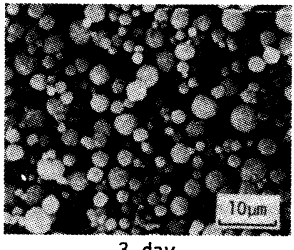

3 day

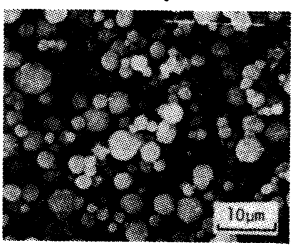

8 day

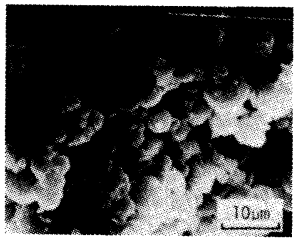

131 day

Fig. 1 Morphological change in the crystallites during the hydrothermal condition for synthesizing ZSM-34 zeolite.
リの $2 / 3$ モルという著量を加え，これにコロイド状のシ リカ懸濁液と混合して，やや白濁したヒドロゲルを生成 させ，これを $100^{\circ} \mathrm{C}$ に長日時保って合成される。しかし， この間の結晶化の進行過程については不明のままであっ た。筆者ら ${ }^{9,10)}$ は，水熱合成時間の経過に伴う結晶成長 の模様を, 電子顕微鏡, 表面積測定, $\mathrm{X}$ 線回折, および メタノールの転化反応試験によって追跡した。その結果,

図 1 のように, ヒドロゲルは 3 日目までに全部球状粒子 に変り，以後外観上の変化は少なく，4箇月を超えると かなり不規則な形状に変化した。これに対し，メタノー ルの転化活性は, 図 2 のように, 初期 3 日頃までにジメ チルエーテルへの生成活性が発現し，以後炭化水素まで 転化する活性に変化し，およそ 1 箇月の後ほぼ選択率は 一定値に到達する傾向となり，4箇月を超えた段階では エチレンが増し，プロピレンが減るなどの変化が見られ た。

結晶化の速度を上げるため, ヒドロゲルを $2.8^{\circ} \mathrm{C} / \mathrm{min}$ の割合で $200^{\circ} \mathrm{C}$ まで昇温し, $200^{\circ} \mathrm{C} に 2 \mathrm{~h}$ 保った場合は, 生成結晶を $540^{\circ} \mathrm{C}$ で焼成しても塩化コリンが焼却でき ず，塩化コリンは結晶内に深く包含されたと考えられる。 メタノール転化の活性は著しく低かった ${ }^{11)}$ 。塩化コリン の量を半分に減らしてから，同様にヒドロゲルを直接高 温加熱する水熱合成（直接加熱法）を行うと，ソーダラ イトを顕著に含む結晶となった。

しかし，ヒドログルを $100^{\circ} \mathrm{C} に 3$ 日間保って，上に 述べた球形粒子を形成させておいてから，200 ${ }^{\circ} \mathrm{C} に 2 \mathrm{~h}$ 加熱する方法 (結晶前駆体加熱法) をとったところ, 典 型的な ZSM-34 を生成した。この前駆体加熱法により

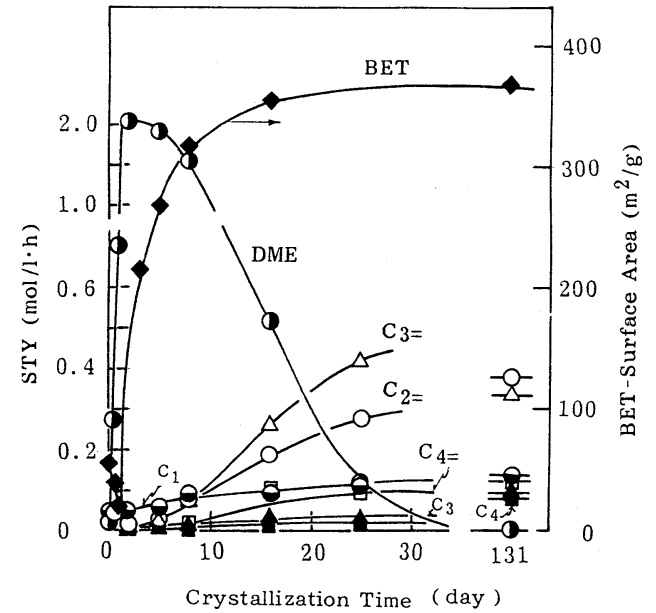

Fig. 2 Effect of crystallization time at $100^{\circ} \mathrm{C}$ on the catalytic activity and surface area of ZSM-34 zeolite. 
Table 1 Properties of zeolites prepared by the rapid crystallization method using seed crystals.

\begin{tabular}{|c|c|c|c|c|}
\hline Ratio of added seed crystals (wt $\%$ ) & 0 & 2.3 & 4.5 & 9.0 \\
\hline length of formed crystal & 13.5 & 4.8 & 3.7 & 2.7 \\
\hline diameter of formed crystal & 5.1 & 1.8 & 1.7 & 1.3 \\
\hline volume of crystal & 270 & 11.5 & 8.3 & 3.8 \\
\hline $\begin{array}{l}\text { BET-surface area } \\
n \text {-Hexane }\end{array}$ & 282 & 287 & 284 & 256 \\
\hline adsorption amount at $20^{\circ} \mathrm{C}$ & 7.95 & 4.65 & 5.14 & 5.74 \\
\hline $\begin{array}{l}\text { effective diffusivity } \\
\text { iso-pentane }\end{array}$ & 3.06 & 5.71 & 9.42 & 6.17 \\
\hline $\begin{array}{l}\text { adsorption amount at } 30^{\circ} \mathrm{C} \begin{array}{r}\left(10^{-2} \mathrm{~g} / \mathrm{g}\right) \\
\text { effective diffusivity } \\
\left(10^{-5} \mathrm{~cm}^{2} / \mathrm{sec}\right)\end{array}\end{array}$ & $\begin{array}{c}1.53 \\
10.1\end{array}$ & & & $\begin{array}{c}1.09 \\
11.0\end{array}$ \\
\hline
\end{tabular}

合成した触媒のメタノール転化性能は, 従来法により 25 日かけて合成した触媒の場合よりも良好であった ${ }^{10) 。 ~}$

一方, 有機結晶化剂の種類を変えて検討した結果, テ トラメチルアンモニウムヒドロキシドを用いた場合には, 直接加熱法でも, メタノールの炭化水素への転化活性も, 低級オレフィン選択性も高い性能をもつゼオライトが合 成できた ${ }^{11,12)}$ 。この迅速水熱合成法による結晶化時間は， ZSM-34 の場合の最長 196 日に比べると $1 / 1,600$ に短縮 されたことになる。しかも，テトラメチルアンモニウム ヒドロキシドを用いた場合は, アルカリの僅か $1 / 20$ モ ルの使用で十分であった ${ }^{11)}$ 。のゼオライト $(Z \mathrm{KU}-2)$ は,オフレタイトとエリオナイトの複合結晶である点 は ZSM-34 と類似しているが，X線回析像は微妙に異 なり ${ }^{13)} ，{ }^{29} \mathrm{Si}$-MASNMR スペクトルの結果 ${ }^{14)}$ からは,
ZSM-34 と ZKU-2 の Si と $\mathrm{Al}$ のミクロ配列は明らか に異なっていることが示された。ZKU-2 の結晶の形状 は直径 $5 \mu$, 長さ $14 \mu$ 程度のまゆ状であり,一般に棒状 の結晶成長に対しては結晶成長核として種結晶の効果 が期待されているので，一度合成した ZKU-2 を乳鉢で $0.2 \mu$ 程度の微粉状として原料液に懸濁しておいてヒド ロゲルを調製し, 迅速水熱合成を行った結果, 生成結晶 は著しく微細となるとともに均一化した。種結晶の添加 量を増すとこの傾向は影著となり, 生成結晶の $9 \mathrm{wt} \%$ 程度種結晶を加えた場合 (ZKU-4) に, 最も均一微細な 結晶が得られた ${ }^{9,15)}$ 。種晶の物性は, 種結晶の添加量に 応じて表 1 のように変化し, メタノール転化性能は図3 のとおり， $\mathrm{C}_{2} \sim \mathrm{C}_{4}$ オレフィン選択率ならびにコーク生 成による劣化が始まるまでの寿命も, 種結晶を使わない

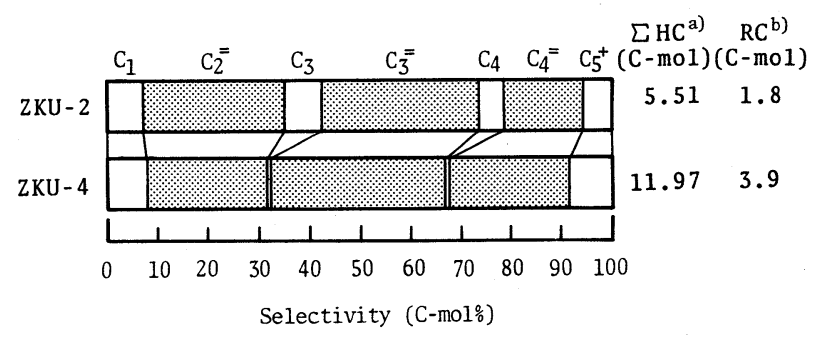

Fig. 3 Comparison of product selectivity of ZKU-2 and ZKU-4

$12 \% \mathrm{MeOH}-88 \% \mathrm{~N}_{2}, \mathrm{SV} 930 \mathrm{~h}^{-1}, 400{ }^{\circ} \mathrm{C} \mathrm{MeOH}$ conversion $100 \%$.

ZKU-2 : Prepared without seed crystals

ZKU -4 : Prepared with seed crystals (9wt\%)

a) Integrated amounts of hydrocarbon formed per unit catalyst volume until beginning of dimethyl ether formation

b) Residual carbon until beginning of dimethyl ether formation 
場合 $(Z K U-2)$ に比べ， 2 倍に延びた。 $\mathrm{C}_{2} \sim \mathrm{C}_{4}$ オレフ イン選択率は $81.3 \mathrm{~mol} \%$ に達し, $\mathrm{C}_{3} \sim \mathrm{C}_{4}$ パラフィンは $2.2 \%$ に過ぎず，エタンの生成は認められなかった。し かし， $\mathrm{CH}_{4}$ 選択率は $7.9 \mathrm{~mol} \%$ あり，物質収支上からむ 必ずュークの生成を伴っている。

種結晶の替りに

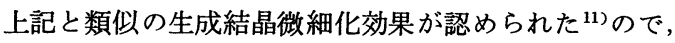

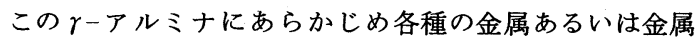
酸化物を担持してから結晶合成した結果, $\mathrm{Ru}$ や $\mathrm{Rh}$ な どを少量担持した場合に,メタノール転化の触媒寿命を さらに 1.3 倍延ばすことができた ${ }^{13)}$ 。この場合, 少量の $\mathrm{CO}_{2}$ の生成を伴うこと, 劣化開始までに析出したコーク の量は変らないことから, 析出コークの一部はメタノー ル分子の中の酸素により，金属触媒表面を媒体として酸 化除去されると考えられる。析出コークを焼却して再生 する際には，この金属は燃焼触媒として作用するため， コークは $400{ }^{\circ} \mathrm{C}$ までの低温で円滑に除去された。

このような金属触媒をゼオライト部分に組み合わせ る方法として，（i）ゼオライトへの金属塩の含浸法,

(ii） ゼオライト中のプロトンとのイオン交換法, (iii) $r-$ アルミナに担持しておいてからゼオライトと混合する方 法, そして (iv) 結晶成長核に用いる $\gamma$ アルミナ微粉 にあらかじめ金属を担持しておく方法，の四種類を試み， メタノール転化性能への影響を比較した結果，上記の結 晶成長核へ担持しておく方法（iv）が最も顕著な効果を 示した ${ }^{13)}$ 。このことは, 迅速水熱合成法によれば, ゼオ ライト結晶の組成とは直接関係のない異種金属化合物を, 結晶核の段階で個々の結晶粒子に取り込むことができる ことを確認したものであって, 後に述べる種々の新規な メタロシリケートの合成処方を設計する上での重要な知 見となった。

4. 2. 沈殿粒子状結晶前駆体からの迅速水熱合成 ZSM-5 ゼオライトを合成する場合, 最初に原料液か ら得られる沈殿は, 上に述べた ZSM-34 やZKU-4の 場合にやや白濁したヒドロゲル状であったのと異なり， 嵩比重は小さいが粒子状の沈殿であり, 遠心分離すれば, 沈殿部と透明な上澄液とに容易に分離される。既にこの 段階で仕込んだ Si 分は殆どこの沈殿部に含まれており， 水熱合成段階でこの沈殿粒子が固相内で結晶化する。従 って, この沈殿自体が結晶前駆体であり，これを裏付け るように, この系では種結晶を投入してもその結晶促進 の効果は見られなかった。そこで, このように沈殿生成 の段階で結晶前駆体が形成される場合の迅速結晶合成の 方法について，次の三つの仮説を立て，その実証を試み た。
4. 2. 1. 混合液相の組成変化を少なくすることによる 結晶前駆体組成の均一化 激しく攪汼しながらC液中に， 所定の $\mathrm{pH}$ に保たれるようにA液と B液を同時に注入し てゲル状沈殿を生成させるが, 特許処方 ${ }^{16)} の \mathrm{~A}, \mathrm{~B}, \mathrm{C}$ 液 組成 (文献 17 の処方 1) ) $^{17}$ ) では, 混合液相の組成は沈殿 の生成量が増すのに伴って大きく変化する。このような 場合, 初期と後期で生成する沈殿の組成や性状は異なり, また初期に生成した沈殿の上に後期に生成する沈殿が覆 うような場合には，その粒子の内外の組成分布が巽なる。 そこで，より均一な組成の結晶を合成するためには，混 合液相の変化ができるだけ小さくなるように原料液の組 成を調整しておくことが必要であろう。この観点から本 研究では, A液とC液の組成を大幅に調整した（文献 17 の処方 4$)^{17)}$ 。但し, 水熱合成時の母液は, ZSM-5 合成 処方のもの (文献 17 の処方の 1$)^{17)}$ のものとした。

4. 2. 2. 結晶前駆体の摩砕による均一微細化 沈殿粒 子固相内で結晶化が起こる場合には，この沈殿粒子の大 きさや組成の分布が, 結晶化の誘導期や速度, ならびに 生成結晶の構造や $\mathrm{Si}$ と $\mathrm{Al}$ の分布などに影響を及ぼす ことになる。そこで，この結晶前駆体をできるだけ均一 微細な状態にしておけば，結晶化速度を上げ，また，形 状, 大きさ, 結晶内組成分布も均一な結晶の合成が期待で きる。そこで本研究では, 擂潰機を使って沈殿粒子を摩 砕した。この際, 沈殿粒子の摩砕がよく進むように, 摩 砕の進行とともににじみ出てくる液相は, 二度にわたり 遠心分離で除去した (文献 17 の処方 3$)^{17)}$ 。このように して摩砕した結晶前駆体を，ZSM-5 合成処方の母液に 戻し，水熱合成に処した。

4. 2. 3. 結晶化速度を考慮したプログラム昇温水熱合 成 一般に行われる等温水熱合成では，通常図 4 の概念 図のように, 結晶化の潜伏期を経て結晶化が進行し, 結 晶化の速度の変化は大きい。結晶化速度が遅くなった期 間に，長い結晶化時間が費やされていると見ることがで きる。ゼオライト結晶は準安定相にあるので, 既に生成 した結晶が長時間水熱合成条件に置かれる場合は, 目的 としない他の相に転位して不均一性を増す可能性も加わ る。そこで, もし結晶構造に変化をもたらさない範囲で あれば，図 5 のように, 結晶化速度ができるだけ均等に なるように, 水熱合成温度の方を変化させて, 結晶化時 間を短縮するとともに生成結晶の性質をより均一とする ことも期待できる。そこで本研究では, 結晶化速度を増 大させるために摩砕処理をほどこした結晶前駆体を用い て, 水熱合成の昇温速度, 段階的昇温などの条件を種々 に変えて ZSM-5 結晶の合成を行い，迅速合成が可能と なることを実証した ${ }^{18)}$ 。例えば， $160^{\circ} \mathrm{C}$ から $210^{\circ} \mathrm{C}$ まで 


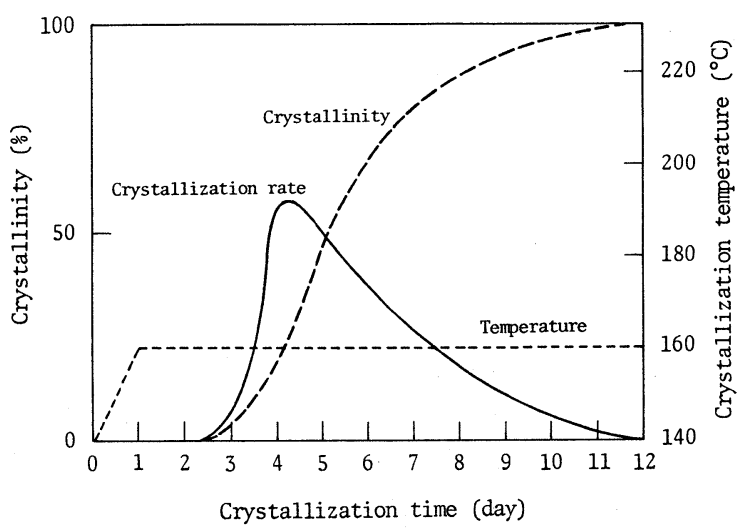

Fig. 4 Conceptional illustration for the change of crystallization rate and crystallinity with time on hydrothermal treatment at a constant temperature in a conventional slow-crystallization method.

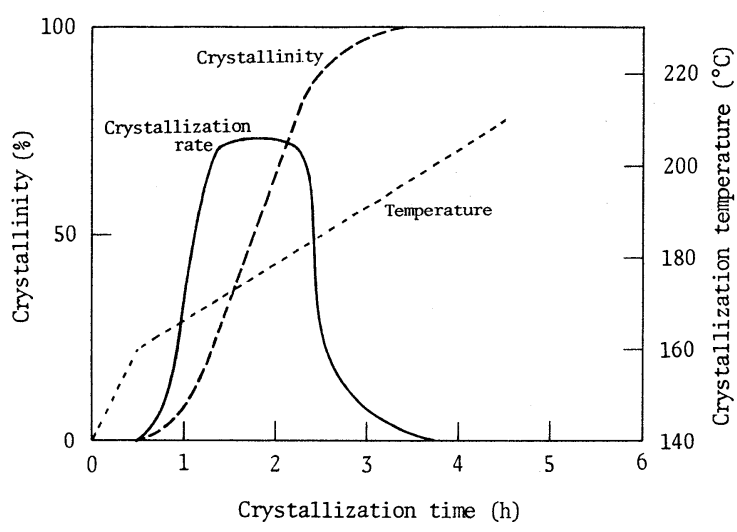

Fig. 5 Conceptional illustration for the change of crystallization rate and crystallinity with time on hydrothermal treatment in the rapid-crystallization method with a programmed temperature rise.

$0.2^{\circ} \mathrm{C} / \mathrm{min}$ で定速昇温する方法（文献 17 の処方 2 ）は その一例である。

以上の方法で調製した結晶を比較すると，いずれも BET 表面積は $385 \pm 11 \mathrm{~m}^{2} / \mathrm{g}$ で, XRD の結果から ZSM-5 で あることが示され, 処方 $1,2,3,4$ の順に結晶粒子は $8 \mu \mathrm{m}$ から $1 \mu \mathrm{m}$ まで微細化, 均一化し, X線マイクロアナラ イザーによる観測の結果, 結晶粒子の表層から内部に向 けての $\mathrm{Si}, \mathrm{Al}$ 分布も均等となった ${ }^{17)}$ 。メタノール転化 活性, ガソリン収率, ガソリン中の芳香族含量も, この 処方の順に明瞭に増加し ${ }^{17)}$ ，上に挙げた三つの条件制御 が，結晶の迅速合成と触媒としての高活性化のために極 (a)

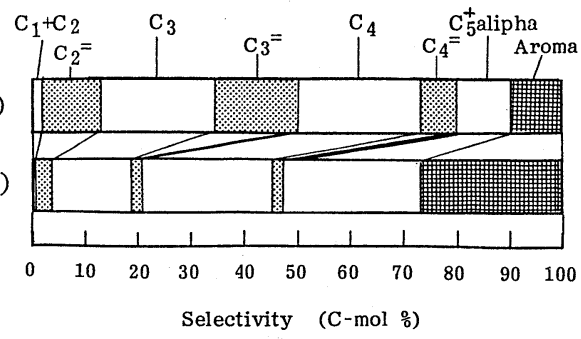

Fig. 6 Performance of methanol conversion on ZSM-5's prepared by different methods. $30 \% \mathrm{MeOH}-70 \% \mathrm{~N}_{2}$, SV $1,100 \mathrm{~h}^{-1}$.

(a) $\mathrm{H}-\mathrm{ZSM}-5(\mathrm{Si} / \mathrm{Al}=40)$ prepared by conventional method Reaction temperature : $400{ }^{\circ} \mathrm{C}, \mathrm{MeOH}$ conversion $100 \%$

(b) $\mathrm{H}-\mathrm{ZSM}-5(\mathrm{Si} / \mathrm{Al}=40)$ prepared by the rapid crystallization method

Reaction temperature : $300{ }^{\circ} \mathrm{C}, \mathrm{MeOH}$ conversion $100 \%$

めて有効であることが確かめられた。

図6 は, 通常処方と, 上記の（1）から（3）までの 改良を加えた処方（文献 17 の処方 4）により調製した

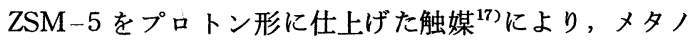
一ル転化性能を比較したものであり, 改良処方では $100^{\circ} \mathrm{C}$ 低温でもメタノールは円滑に炭化水素に完全に転化し， オレフィンの生成が減り, ガソリン留分が顕著に増え, この処方により $\mathrm{Al}$ が効率よく結晶内に分散されより効 果的に触媒活性点である酸点の形成を準備したことが実 証された ${ }^{19)}$ 。

\section{5. 金属を微量含むメタロシリケートの合} 成とメタールの転化性能

一般に緩慢な結晶合成過程では，結晶組成以外の異物 は排除されて, 純粋な単結晶の生成が見られるが, 迅速 合成過程では，前節 (4.1.) に述べた例 ${ }^{13)}$ のように，異 物を包含した結晶が生成する可能性が大きいと期待され る。そこで本研究では，ZSM-5 ゼオライトのペンタシ ル型細孔開口と三次元細孔連結の棈造の特徴 ${ }^{3,7)}$ を温存し て, 酸性度と細孔径の微妙な調整を試みることを意図し, 迅速水熱合成法 (文献 17 の処方 4) を用いて, 各種の遷 移金属成分を ZSM-5 の Al の替りに取り込んだ高シリ カ結晶の合成を試みた。まず, $\mathrm{Si} / \mathrm{Metal}$ 仕込原子比が 3,200 という微量の範囲で調製したところ, 結晶の粒子 形状 (晶癖) はそれぞれ著しく異なった ${ }^{17) 。 メ タ ノ ー ル ~}$ 転化生成物の選択率にも，図7のように差異を生じた ${ }^{20,21)}$ 。 この図からわかるとおり，Al-シリケートすなわち Z ZSM -5に比べて, $\mathrm{Ga}-, \mathrm{Cr}-, \mathrm{V}-$ シリケートなどガソリン 選択率の高いものと, $\mathrm{Fe}-, \mathrm{Co}-, \mathrm{Pt}-$ シリケートなど 


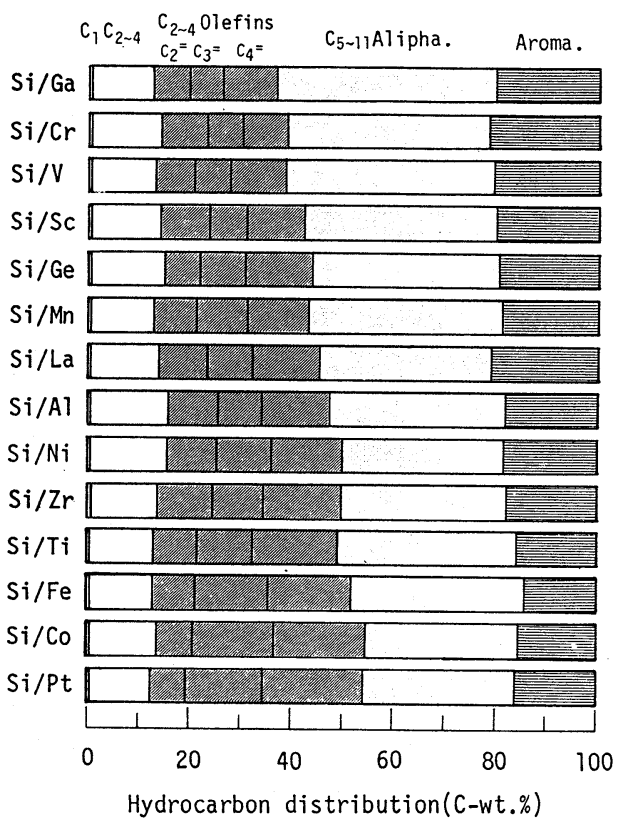

Fig. 7 Hydrocarbon distribution in methanol to hydrocarbon conversion on various metallosilicates.

Catalyst : $\mathrm{Si} / \mathrm{Metal}$ atomic ratio 3,200

Feed gas : $20 \% \mathrm{MeOH}-80 \% \mathrm{~N}_{2}$, SV $2,000 \mathrm{~h}^{-1}, 300^{\circ} \mathrm{C}$

$\mathrm{C}_{2} \sim \mathrm{C}_{4}$ オレフィン選択率の高いものとが識別される。 ガソリンと芳香族の選択率の序列 ${ }^{20)}$ は, 次のようにほぼ

$$
\begin{aligned}
& \text { ガソリン } \mathrm{Ga}>\mathrm{V} \approx \mathrm{Cr}>\mathrm{Sc}>\mathrm{Mn} \approx \mathrm{Ge}>\mathrm{La}> \\
& \mathrm{Al}>\mathrm{Ti}>\mathrm{Zr} \approx \mathrm{Ni}>\mathrm{Fe}>\mathrm{Pt} \approx \mathrm{Co} \\
& \text { 芳 香 族 }: \mathrm{Cr}>\mathrm{La}>\mathrm{V} \approx \mathrm{Ga} \approx \mathrm{Sc}>\mathrm{Ge}>\mathrm{Mn} \approx \\
& \mathrm{Ni} \approx \mathrm{Al} \approx \mathrm{Zr}>\mathrm{Pt} \approx \mathrm{Ti}>\mathrm{Co}>\mathrm{Fe} \\
& \text { オレフィン }: \mathrm{Ga} \approx \mathrm{Cr}<\mathrm{V}<\mathrm{Sc} \approx \mathrm{Ge}<\mathrm{Mn}<\mathrm{La} \approx \\
& \mathrm{Al}<\mathrm{Ni}<\mathrm{Zr} \approx \mathrm{Ti}<\mathrm{Fe}<\mathrm{Co} \approx \mathrm{Pt}
\end{aligned}
$$

共通し, また $\mathrm{C}_{2} \sim \mathrm{C}_{4}$ オレフィン選択率の序列はガソリ ンの多い順とは逆となっている。このことは, H-ZSM-5 ゼオライトの酸点上で起こる, 先に述べた逐次反応の経 ${ }$ 過 ${ }^{22}$ に照らして, 各触媒の酸性質を反映しているものと 見ることができる。

\section{6. 金属を多量含むメタロシリケートの合成}

前節で述べたように, Si/Metal 原子比が 3,200 という 微量では，金属がペンタシル型シリカ結晶の格子に組み 込まれているか否かはわかりにくい。これらの新規なメ タロシリケートの物性と触媒性能をより一層明らかにす るため, 金属の含量の異なるメタロシリケートの合成を
試みた。

前記のメタロシリケート群のうち, メタノールからガ ソリンもしくは芳香族に富んだ生成物を与える $\mathrm{Ga}$-シリ ケートと V-シリケートについては，少なくとも $\mathrm{Si} / \mathrm{Ga}$ 原子比 $21^{17,23)}, \mathrm{Si} / \mathrm{V}$ 原子比 $70^{24)}$ の比較的高濃度まで 結晶格子に組み込むことが可能なことを見い出し，それ ぞれ，低級パラフィンの芳香族化性能 ${ }^{23)}$, メタールの 炭化水素への転化性能 ${ }^{24)}$ に対して，これらの組み込み金 属の濃度が影響を与えることを観測した。

一方, メタノールからオレフィンに富んだ生成物を与 える $\mathrm{Fe}$-シリケートについては, 少なくとも $\mathrm{Si} / \mathrm{Fe}$ 原子 比 12 の高濃度まで, 仕込み鉄量はほぼ全量結晶に取り 込まれることを見い出した ${ }^{21,25)}$ 。Fe を含んだシリケー トのX線回折像 ${ }^{21)}$ は ZSM-5 の場合と同様であり，酸化 鉄に帰属される回折像を含んでいないので, $\mathrm{Fe}$ の酸化物 は極めて微細な状態，おそらく結晶格子に取り込まれた 形で結晶内に分散していることがわかる。またこのこと は, 最も $\mathrm{Fe}$ 濃度の高い結晶 $\left(\mathrm{Fe}_{2} \mathrm{O}_{3}\right.$ として $\left.10 \mathrm{wt} \%\right)$ で も, 含有する有機物を焼却するため $540{ }^{\circ} \mathrm{C}$ の空気で処理 した段階でなお乳黄白色を呈していること，20〜 $50 \mathrm{~atm}$ の加圧下で合成ガスの転化がごく僅かしか起こらないこ と ${ }^{26)}$ などからも支持される。

$\mathrm{Fe}$ を僅か ( $\mathrm{Si} / \mathrm{Fe}$ 原子比 3,200) に含むだけで, 合成結 晶の晶癖は ZSM-5 とは著しく異なり ${ }^{25)}$ ，このことは， 特に $\mathrm{Fe}$ が微量の場合は, $\mathrm{Fe}$ の水酸化物ないし酸化物が 結晶成長の核としての役割を含んでいることを示唆する。 合成結晶粒子を, そのままの状態と, メノウ乳鉢によっ て $0.2 \mu \mathrm{m}$ 程度の微細な粒子に摩砕した試料について,

X線マイクロアナライザーで Si と Fe の分布を比較した

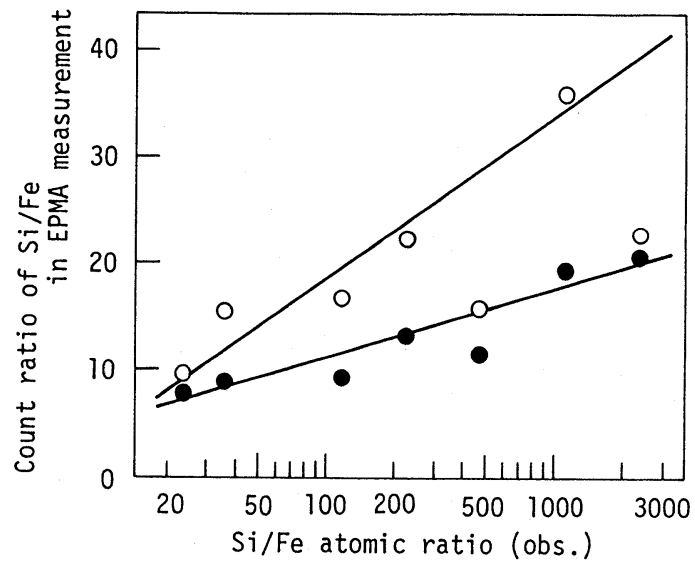

Fig. 8 Difference in concentration of Fe between surface and bulk of $\mathrm{Fe}$-silicate crystals. $\mathrm{O}$ : unground, $\mathrm{O}$ : ground 
結果, 図 $8^{21,25)}$ のように, 明らかに摩砕した場合の方が, $\mathrm{Fe}$ 濃度が大きくなっている。この傾向は, 結晶全体に 含まれる $\mathrm{Fe}$ の濃度が低いほど著しい。即ち, Fe 濃度が 低い場合の結晶の表層は, Si 分に富み, 結晶粒子内部の 方が表層よりも $\mathrm{Fe}$ は濃くなっている。 Fe 濃度が高くな ると結晶外表面付近と内部との $\mathrm{Fe}$ 濃度の差は殆どな くなる。このような粒子内の $\mathrm{Fe}$ 浱度の分布の仕方は, 触媒性能, 特に選択性, にとって, 以下に述べるように 極めて好都合である。

ゼオライトは, $\mathrm{Al}$ の 3 価カチオンを $\mathrm{Na}$ などのアルカ リ金属のカチオンが補って，4 価の $\mathrm{Si}$ カチオンと同様 に電気的中性を保つが, この $\mathrm{Na}$ をプロトンで置換する とき強い固体酸性が発現し，これが触媒の活性点として 作用する。 $\mathrm{Fe}$-シリケートに㧍いても，後に述べるよう に 3 価の $\mathrm{Fe}$ イオンがゼオライトにおける $\mathrm{Al}$ と同様の役 割を果して酸性点の発現に寄与している。生成物におけ る分子形状選択性は，結晶粒子内部の細孔の大きさによ って規制を受けるので，粒子外表面に酸点が分布してい ると非選択的反応が混入してくる。結晶内拡散は, 流通 気相における分子拡散に比べ非常に遅い ${ }^{27)}$ ので, 粒子外 表面積の内部表面に対する比率は小さくても，この表層部 で起こる反応の内部で起こる反応に対する比率はかなり 大きくなる。この問題に関してかって筆者ら ${ }^{28)}$ は, $\mathrm{H}-$ ZSM-5 粒子外表面の酸点を作動させないため, 細孔内 には入り込めないような分子の大きさの有機塩基（例え ばキノリン）を前処理したり，原料ガスの中に混入して 供給するなどの処置をして,メタノール転化生成物のう ち $\mathrm{C}_{2} \sim \mathrm{C}_{4}$ オレフィンの選択性を向上させた。しかし, このような部分的な修飾による方法よりも，本研究の $\mathrm{Fe}$-シリケートの例のように, 外表面が酸性の殆どない シリカ層で覆われているといら構造によって, 触媒粒子 自体にその性能が備わっていることの方が望ましい。ま たこのような構造をとることによって, 結晶粒子が小さ く触媒有効係数が大きくなって単位触媒量当りの触媒活 性が増しても, 非選択的触媒反応が生起する外表面の面 積が増えているにもかかわらずその部分は反応に関与せ ず，従って，反応の高い選択性が期待できる。

$\mathrm{Fe}$-シリケートの酸点量は, $50^{\circ} \mathrm{C}, 1 \mathrm{~atm}$ において, $\mathrm{N}_{2}$ 希釈の $5 \% \mathrm{NH}_{3}$ の吸着飽和の後, $\mathrm{N}_{2}$ で溶出させて から測定した TPD 曲線より算出した。TPD 曲線 ${ }^{21)}$ は典 型的な $\mathrm{H}-\mathrm{ZSM}-5$ に見られるのと同様に, $300^{\circ} \mathrm{C}$ 付近 を境とする低温, 高温の二つのピーク ${ }^{299}$ に分割された ${ }^{21,30)}$ 。 これらは, 弱酸点と強酸点に対応するものであるが, $\mathrm{Fe}$ 含量の増加とともに, 両酸点とも増加し, $\mathrm{Si} / \mathrm{Fe}$ 原子比 40 付近で最大を示し, それ以上に $\mathrm{Fe}$ の含量が増すと,
酸点量はやや減少する傾向となった。

$$
\begin{aligned}
& \text { 7. } \mathrm{Fe} \text {-シリヶートによるメタノールの低 } \\
& \text { 級オレフィンへの定量的転化 }
\end{aligned}
$$

上に述べたように，微量の金属の水酸化物あるいは酸 化物がメタロシリケート結晶成長の核形成に大きなかか わりを持っていることが示されたので，原料鉄塩の種類 や濃度を変えて $\mathrm{Si} / \mathrm{Fe}$ 原子比 3,200 の $\mathrm{Fe}$-シリケート を合成し,メタノール転化性能を比較した。その結果, $\mathrm{Fe}\left(\mathrm{NO}_{3}\right)_{3}$ を原料塩に用いて, 基淮処方 ${ }^{21)}$ (文献 17 の 処方 4$)^{17)}$ の場合の $1 / 2 \sim 1 / 3$ にこの鉄塩水溶液を希釈 したとき，オレフィン選択性が特異的に高くなる $\mathrm{Fe}$-シ リケートが得られた ${ }^{26,32)}$ 。この触媒を用いて，メタノー ル $20 \%-\mathrm{N}_{2} 80 \%$ のガスを SV $8,000 \mathrm{~h}^{-1}$ の条件で流通し， 温度の依存性を見たのが図 $9^{20,21)}$ である。 $295^{\circ} \mathrm{C}$ に扔い て,メタノールの転化率は $33.0 \%$ (炭化水素へ $16.8 \%$, ジメチルエーテルー $16.2 \%$ ) であるが, 選択率は, エチ レン $54.7 \%$, プロピレン $41.5 \%$, ブテン $1.4 \%, \mathrm{C}_{2} \sim \mathrm{C}_{4}$ オレフィンの合計 $97.6 \%$ で, 残りは痕跡量のメタンと $\mathrm{C}_{5}^{+}$オレフィンであった。 $300^{\circ} \mathrm{C}$ 以上で転化率は急激に 増え， $320^{\circ} \mathrm{C}$ 以上で転化率, 選択率とも一定となる傾 向を示した。 $350^{\circ} \mathrm{C}$ での転化率は $82.0 \%$ (炭化水素へ $78.0 \%$ ，ジメチルエーテルへ $4.0 \%$ ）となり，エチレン が減り,ブテンが増えた。 $\mathrm{C}_{2} \sim \mathrm{C}_{4}$ オレフィン $61 \%$ とオ レフィンに富むガソリン $37 \%$ とで $98 \%$ を占め, $\mathrm{C}_{2} \sim \mathrm{C}_{4}$ パラフィンは $2 \%$ に過ぎなかった。芳香族炭化水素はま ったく生成せず，少なくとも 25 時間の使用中，コークの 生成や劣化の徴候はまったく認められなかった。 $295^{\circ} \mathrm{C}$ 付近での反応で, メタノールから炭化水素へ転化した部

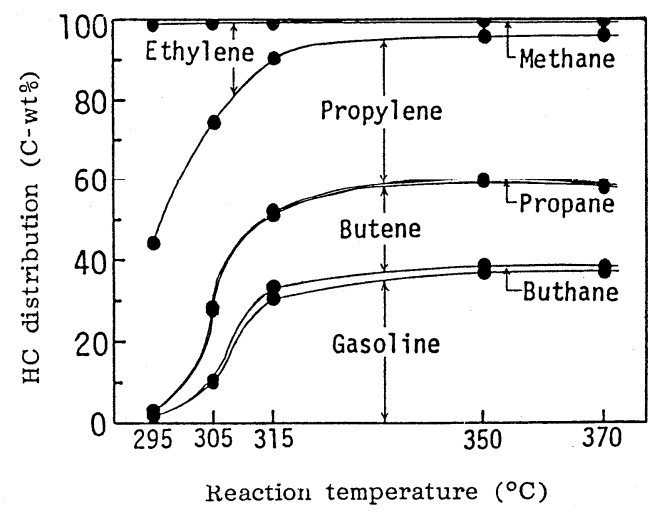

Fig. 9 Effect of temperature on the distribution of hydrocarbons formed from methanol on the improved $\mathrm{Fe}$-silicate catalyst. Feed gas : $20 \% \mathrm{MeOH}=80 \% \mathrm{~N}_{2}, \mathrm{SV} 2,000 \mathrm{~h}^{-1}, 30{ }^{\circ} \mathrm{C}$ 
分の反応は,

$$
\mathrm{nCH}_{3} \mathrm{OH} \rightarrow\left(\mathrm{CH}_{2}\right)_{\mathrm{n}}+\mathrm{nH}_{2} \mathrm{O}, 2 \leq \mathrm{n} \leq 4
$$

で表わされ，芳香族の生成を伴わないためコークの生成 が起こらないこと, および脱水素しないため生成オレフ インが低級パラフィンに転化しないことが理解される。 $\mathrm{Fe}$-シリケートの $\mathrm{Fe}$ 濃度を増すと, $\mathrm{C}_{2} \sim \mathrm{C}_{4}$ オレフィ ンの選択率が増加したが, これは, ZSM-5 において Al を増すとオレフィンが減って芳香族と低級パラフィンが

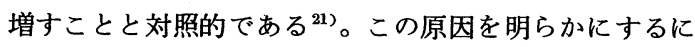
は, 今後のより詳細な検討が必要である。

\section{8. $\mathrm{Fe}$-シリヶートによる低級オレフィン の高オクタン価ガソリンへの定量的転化}

筆者ら ${ }^{33}$ は，合成ガスから中間にメタノールを経由し てガソリンを合成する目的の研究において，低温メタ， ール合成触媒と H-ZSM-5 ゼオライトとの組み合わせ 触媒を検討した際, 低温メタノール合成触媒の最適作動 温度域である $300^{\circ} \mathrm{C}$ 以下の温度で, メタノールを円滑に 炭化水素に転化するような高活性 H-ZSM-5 が必要と なった。ところがこの反応は自己触媒的に進む ${ }^{34,35)}$ ため, このような低温域では急に炭化水素への転化が起こらな くなる。そこで筆者ら ${ }^{36)}$ は，この自己触媒的な段階を解 消させて低温から円滑に反応が進行するための反応促進 剤について研究し, エタノール，2-プロパノール，ア リルアルコールなどの微量添加, あるいは, エチレン, プロピレンなどの低級オレフィンの原料ガス中への添加 や，これら低級オレフィンによる H-ZSM-5 の前処 理によっても，顕著な反応促進効果があることを見い出

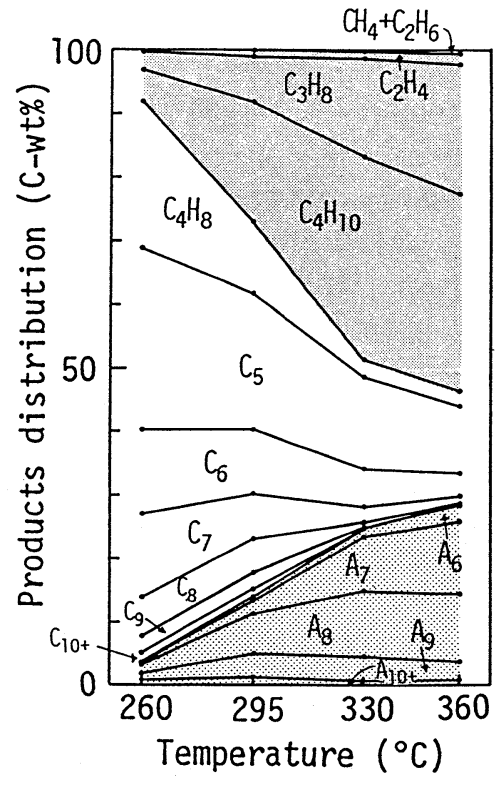

Fig. 10 Effect of temperature on the product distribution of propylene conversion on $\mathrm{H}-\mathrm{ZSM}-5$.

Feed gas : $\mathrm{C}_{3} \mathrm{H}_{6} 100 \%$, GHSV $900 \mathrm{~h}^{-1}$

した。更に、オレフィンを $\mathrm{H}-\mathrm{ZSM}-5$ に通じたところ, 高収率でガソリンが得られることを見い出した ${ }^{37,38)}$ 。と ころが，H-ZSM-5 を触媒とした場合, 図 $10^{20)}$ のう に, 昇温に伴い芳香族炭化水素と低級パラフィンが顕著 に増加し，ガソリンの選択率は低下した。オレフィンの オリゴマーが芳香族化する際に生じる水素が, H-ZSM-5 上で低級オレフィンを水素化するためである。このオレ

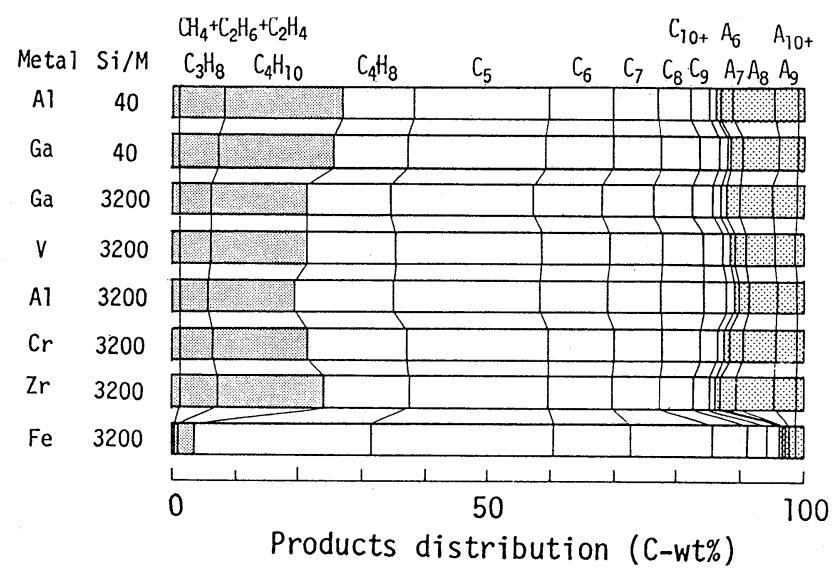

Fig. 11 Product distribution of propylene conversion on various metallosilicates. Feed gas : $\mathrm{C}_{3} \mathrm{H}_{6} 17 \%-\mathrm{N}_{2} 83 \%$, GHSV $900 \mathrm{~h}^{-1}, 295^{\circ} \mathrm{C}$ 
フィン転化反応は発熱反応であるので，この触媒のよう に, 触媒層の温度上昇に伴って容易にガソリンの選択率 が低下寸ることは望ましくない。そこで，種々のメタ口 シリケートを触媒として, 窒素で $17 \%$ に希釈したプロ ピレンを原料にしてプロピレン転化性能を比較した結果, 図 11 のように，前節 (7) で述べた $\mathrm{Fe}$-シリケート $(\mathrm{Si} /$ $\mathrm{Fe} 3,200)$ の場合に, $\mathrm{C}_{3}$ 以下の炭火水素は僅か $(1.2 \%)$ で, 少しのブタン $(2.4 \%)$ のほか, ブテン $(28.0 \%)$ と $\mathrm{C}_{5} \sim \mathrm{C}_{11}(68.4 \%)$ とで計 $96.4 \%$ が占められた ${ }^{38)}$ 。ZSM -5 や他のメタロシリケートに比べ, 芳香族炭化水素が 特に少ない $(3.8 \%)$ 。

プロピレン濃度を $50 \%$ まで上げると $\mathrm{C}_{4}$ 以下のパラ フィンは更に減り, ブテンも著しく減って $\mathrm{C}_{5}^{+}$が増加し た。純プロピレンを通じるとほぼ定量的 (99\%) に液状 炭化水素に転化し，この液は $\mathrm{C}_{5} \sim \mathrm{C}_{11} 87 \%$,ブテン $11 \%$ を含み，芳香族は $10 \%$ と比較的低いが $\mathrm{C}_{5}^{+}$留分中に内 部オレフィンが多く, イソ体に異性化されているため, 実測オクタン価は 95 という高い值を示した ${ }^{38}$ 。 $。 \mathrm{SV}$ $900 \mathrm{~h}^{-1}$ から $4,500 \mathrm{~h}^{-1}$ まで 5 倍に上げても，な拉生成物 はすべて液状炭化水素であり, やや軽質化したが, イソ-

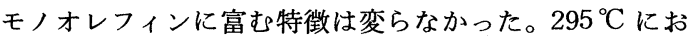
いて SV 4,500 $\mathrm{h}^{-1}$ でプロピレンを導入したとき, プロピ レン転化率 $95.6 \%$, 空時転化量 $193 \mathrm{~mol} / \mathrm{l} \cdot \mathrm{h}(8.09 \mathrm{~kg} /$ 1.h）という極めて高い速度で, ほぼ定量的に高オクタン 価ガソリンに転化するという結果が得られた ${ }^{38)}$ 。このよ うに大きな反応速度が得られることは, 触媒の活性点近 傍において，反応原料，中間体，生成物などによる反応 抑制作用が存在しないことを強く示唆するもので，固体 触媒としては極めて特異的なことと言わなければならな い。

$\mathrm{Fe}$-シリケートは，エチレンおよびブテンの 4 種の異 性体に対しても，プロピレンの場合とほぼ類似の生成物 を与えた。 $\mathrm{Si} / \mathrm{Fe}$ 原子比 3,200 の $\mathrm{Fe}$ 低濃度のシリケート では, エチレンの転化速度は低かった ${ }^{38}$ )が, $\mathrm{Si} / \mathrm{Fe}$ 原子 比 400 12 の $\mathrm{Fe}$ 高濃度のシリケートを用いることによ り、プロピレン, ブテンの場合と同等の転化速度が得ら れた ${ }^{39}$ 。

このように，低級オレフィンから， $\mathrm{C}_{11}$ までのイソ-モ ノオレフィンが定量的に生成する反応は,

$$
\begin{aligned}
& \left(\mathrm{CH}_{2}\right)_{\mathrm{n}} \\
& 2 \leqq \mathrm{n} \leqq 4
\end{aligned} \longrightarrow \begin{aligned}
& \left(\mathrm{CH}_{2}\right)_{1} \\
& 4 \leq \mathrm{l} \leq 11
\end{aligned}
$$

で示され, 芳香族化に伴ら脱水素, 水素添加, 縮合芳香 族の形成もないため，低級パラフィンやコークの生成も 起こらず，触媒劣化を伴わないことが期待された。尖際
には，選択率にして $10 \%$ 未満の芳香族炭化水素が生成 しているので，上式の反応が完全に選択的に起こってい るのではないが, SV 1,000 2,000 $\mathrm{h}^{-1}$ でプロピレン転化 の連続流通試験を試みた結果, SV $1,000 \mathrm{~h}^{-1}$ 換算で 100 時間後も活性の変化を認めず，またコークによる着色も 起こらなかった

現在, $\mathrm{Fe}$-シリケートのほかにも， $\mathrm{Ni}$-シリケート， Co-シリケートなど, メタノール転化においてオレフィ ン選択性の大きかった触媒群に抬張して,オレフィンか らガソリン合成の高選択的合成能の高い触媒の開発を継 続中である ${ }^{40) 。 ~}$

\section{9. おわりに}

常圧の温和な条件下に，低級オレフィン類から高い反 応速度で定量的に高オクタン価ガソリンが合成できるこ とは，これらの新規なメタロシリケート触媒が，従来の 重合ガソリン合成に用いられた触媒とは異なり，分子形 状選択性と適度に強い固体酸性により, 低級オレフィン のオリゴメリゼーションと異性化が同時に行われている もので, 結晶粒子の表層が酸性のないシリカ層で覆われ ている特徴も，高い選択率の維持と，表層でのコーク生 成の抑制に役立っていると見られる。

同じ触媒でも, メタノールやジメチルエーテルの分圧 が共存すると, オレフィンのオリゴメリゼーションの進 行が抑制され，メタノールからオレフィンの高選択合成 ができるので，今後これらの反応機構の詳細と触媒構造 との関連を明らかにして行きたい。

これらのメタロシリケートを実用工業触媒として完成 することによって

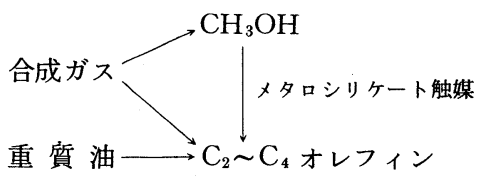

$$
\stackrel{\text { メタロシリケート触媒 }}{\longrightarrow} \text { 高オクタン価ガソリン }
$$

という, 各種の石油代替資源からの新規な高選択的ガソ リン合成のルートの成立が期待できる ${ }^{20)}$

ご指導賜った京都大学名誉教授武上善信先生ならびに 協力頂いた教官, 大学院生, 卒研生, 研究生の方々（引 用文献に記載）に感謝いたします。

（昭和 60 年 9 月 10 日受理）

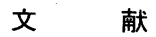

1）松浦 保, 化学と工業, 32, 918 (1979)

2）乾 智行，表面，20,57 (1982) 
3）乾 智行, 表面, 23, 518 (1985)

4) 門田憲章, 触媒工学講座第 8 巻, 触媒反応 (3), 重合, 触媒学会編, 地人書館, 1965, p. 1

5) 丸谷健一, 触媒講座第 8 巻, 工業触媒反応 I, 触媒学会編, 講談社, 1985, p. 41

6）乾 智行, セラミックデータブック' 83 , 工業製 品技術協会, 1983 , p. 39

7）乾 智行, 触媒, 25, 261 (1983)

8）乾 智行, 触媒講座第 9 巻, 工業触媒反応 II, 触媒学会編, 講談社, 1985, p. 52

9) T. Inui, T. Ishihara, N. Morinaga, G. Takeuchi, H. Matsuda, Y. Takegami, Ind. Eng. Chem. Prod. Res. Dev., 22, 26 (1983)

10) T. Inui, N. Morinaga, Y. Takegami, Appl. Catal., 8, 187 (1983)

11）乾 智行, 石原敬之, 森永紀子, 竹内玄樹, 荒木英一，蟹江敏広，武上善信，日化，221 (1982)

12) T. Inui, T. Ishihara, Y. Takegami, J. Chem. Soc., Chem. Commun., 1981, 936

13) T. Inui, G. Takeuchi, Y. Takegami, Appl. Catal., 4, 211 (1982)

14）中田真一, 工藤英彦, 浅岡佐知夫, 高橋弘光, 石油学会第 26 回研究発表会要旨集, p. 37 (1984)

15) T. Inui, N. Morinaga, T. Ishihara, T. Kanie, Y. Takegami, J. Catal., 79, 176 (1983)

16) C. J. Plank, E. J. Rosinski, A. B. Schwartz, USP, 1, 402, 981 (1974)

17) T. Inui, O. Yamase, K. Fukuda, A. Itoh, J. Tarumoto, N. Morinaga, T. Hagiwara, Y. Takegami, 8th Intern. Congr. Catal., Berlin, 1984, Preprints, p. 569

18）乾 智行, 森永紀子, 山瀬 修, 投稿準備中

19) T.Inui, Y.Takegami, Pan-pacific Synfuels Confer., Tokyo, 1982, p. 145

20) T. Inui, J. Japan Petrol. Inst., 28, 279 (1985)

21) T. Inui, H. Matsuda, O. Yamase, H. Nagata, K. Fukuda, T. Ukawa, A. Miyamoto, J. Catal., 投稿中

22) C. D. Chang, A. J.Silvestri, J. Catal., 47, 249 (1977)

23）岡住文郎, 牧野義典, 松田洋和, 乾 智行, 日化第 50 春季年会講演予稿集 I, p. 174 (1985)
24) T. Inui, D. Medhanavyn, P. Praserthdam, K. Fukuda, T. Ukawa, A. Sakamoto, A. Miyamoto, Appl. Catal., 印刷中

25）長田秀夫, 松田洋和, 黒田 徹, 吉川正晃, 山瀬 修, 乾 智行, 日化第 50 春季年会講演予 稿集 I, p. 715

26）乾 智行, 松田洋和, 福田晃一, 鵜川隆世, 長田秀夫, 第 14 回石油化学討論会要旨, p. 217 (1984)

27）乾 智行, 触媒講座第 1 巻, （基礎編 1 ） 触媒と反応速度, 触媒学会編, 1985, 印刷中

28) T. Inui, K. Fukuda, N. Morinaga, Y. Takegami, J. Japan Petrol. Inst., 27, 188 (1984)

29) T. Inui, H. Matsuda, Y. Takegami, Proc. 6th Intern. Zeolite Confer., D. Olson, A. Bisio ed., Butterworths, 1984, p. 316

30）乾 智行, 松田洋和, 黒田 徹, 長田秀夫, 吉川正晃, 第 2 回シー・ワン触媒化学シンポジウ ム要旨, p.75 (1985)

31) T. Inui, T. Suzuki, M. Inoue, Y. Murakami, Y. Takegami, Studies, Sur. Sci. Catal., 18, 201 (1984)

32）松田洋和, 乾 智行, 昭和 60 年度触媒研究発表 会 4F05 (1985)

33) T. Inui, T. Hagiwara, O. Yamase, K. Kitagawa, H. Yamaguchi, Y. Takegami, J. Japan Petrol. Inst., 28, 225 (1985)

34) H. Y.Chen, W. J. Regan, J. Catal., 59, 123 (1979)

35) Y. Ono, T. Mori, J. Chem. Soc., Faraday Trans. I, 77, 2209 (1981)

36) T. Inui, T. Hagiwara, J. Tarumoto, J. Japan Petrol. Inst., 28, 341 (1985)

37) 輏本潤一, 乾 智行, 第 52 回触媒討論会 (A) 予稿集, p. 220 (1983)

38）乾 智行, 樽本潤一, 岡住文郎, 松田洋和, 第 14 回石油化学討論会予稿集, p. 229 (1984)

39）岡住文郎, 松田洋和, 乾 智行, 日化第 50 春季 年会講演予稿集 I, p. 706 (1985)

40）長田秀夫, 岡住文郎, 松田洋和, 大東 昇, 乾 智行, 昭和 60 年度触媒研究発表会予稿集, 4 F 10 (1985) 